\title{
Pengaruh Variasi Latihan Penyerangan Dengan Menggunakan Inverted Winger Terhadap Hasil Shooting Dalam Permainan Sepak Bola Pada Atlet SSB TGM Medan
}

\section{The Influence of Attacking Exercise Variations Using Inverted Winger on Shooting Results in Football Games for SSB TGM Medan Athletes}

\author{
Erwin Saputra Gultom ${ }^{1}$, Dewi Endriani ${ }^{2}$ \\ ${ }^{1,2}$ Fakultas Ilmu Keolahragaan, Universitas Negeri Medan \\ Email: zeeoura@gmail.com
}

\begin{abstract}
ABSTRAK
Penelitian ini bertujuan untuk mengetahui tentang pengaruh bentuk latihan variasi - variasi penyerangan dengan menggunakan inverted winger terhadap hasil shooting pada atlet SSB TGM Medan Tahun 2020. Metode Penelitian ini menggunakan eksperimen lapangan dengan teknik pengambilan data digunakan tes dan pengukuran. Lokasi penelitan ini dilaksanakan di lapangan sepakbola Thamrin Graha Metropolitan Medan, terletak dijalan Graha Metropolitan Kampung Lalang dengan sampel 10 orang. Sampel dijadikan satu kelompok sehingga mendapat bentuk variasi-variasi latihan teknik yang sama, yaitu latihan shooting. Penelitian dilaksanakan mulai dari bulan Februari sampai dengan Maret tahun 2020. Hasil analisis dengan uji-t menujukkan bahwa: Hipotesis menujukkan bahwa nilai $t_{\text {hitung }}$ sebesar 5,79. Sedangkan nilai $t_{\text {tabel }}$ pada taraf signifikan $=2,26$ dengan $\mathrm{dk} n-1(10-1=9)$ diperoleh $t_{\text {tabel }}$ sebesar 2,26, ini berarti menujukkan bahwa $t_{\text {hitung }}$ yang diperoleh lebih besar dari $t_{\text {tabel }}\left(t_{\text {hitung }}=5,79>t_{\text {tabel }} 2,26\right)$ berarti Ho ditolak dan Ha diterima. Jadi variasi - variasi latihan penyerangan dengan menggunakan inveted winger memberikan pengaruh yang signifikan terhadap peningkatan hasil shooting dalam permainan sepakbola pada atlet SSB TGM Medan Tahun 2020.
\end{abstract}

Kata Kunci: Variasi Latihan, Penyerangan, Inverted Winger, Shooting, Sepak Bola

\begin{abstract}
This study aims to determine the effect of the form of training with inverted winger variations on the shooting results of the 2020 Medan TGM SSB athletes. This research method uses field experiments with data collection techniques used tests and measurements. The location of this research was carried out in the Thamrin Graha Metropolitan Medan football field, located on the Graha Metropolitan street, Lalang Village with a sample of 10 people. The sample is made into one group so that they get the same variation of technical exercises, namely shooting practice. The research was carried out from February to March 2020. The results of the t-test analysis show that: The hypothesis shows that the t-count value is 5.79. While the value of $t$ table at the significant level $=2.26$ with dk n-1 $(10-1=9)$ obtained $t$ table of 2.26 , this means showing that the $t$ count obtained is greater than $t$ table ( $t$ count $=5.79>t$ table 2,26 ) means that Ho is rejected and $\mathrm{Ha}$ is accepted. So the variations of attack training using inveted winger have a significant
\end{abstract}


Pengaruh Variasi Latihan Penyerangan Dengan Menggunakan Inverted Winger Terhadap Hasil Shooting Dalam

Permainan Sepak Bola Pada Atlet SSB TGM Medan

effect on the improvement of shooting results in soccer games for SSB TGM Medan athletes in 2020.

\section{Keywords: Practice Variations, Offensive, Inverted Winger, Shooting, Soccer}

\section{PENDAHULUAN}

Olahraga secara umum adalah suatu kegiatan yang bisa menyehatkan diri dari dalam maupun luar tubuh atau yang biasa disebut juga dengan sehat jasmani maupun rohani. Olahraga berkembang semakin luas dan menjadikan banyak bidang kajian dalam olahraga dimana hal tersebut menjadi sebuah profesi bagi pelakunya (Kumbara, H., 2018). Olahraga menjadi salah satu kebutuhan masyarakat sekarang ini. Olahraga mengajarkan pada seseorang akan kedisiplinan, jiwa sportivitas, tidak mudah menyerah, mempunyai jiwa kompetitif yang tinggi, semangat bekerja sama, mengerti akan adanya aturan, dan berani mengambil keputusan.

Seiring berkembangnya zaman, olahraga sepak bola menjadi sangat populer. Olahraga sepakbola pun semakin berkembang dengan banyaknya klub - klub sepakbola yang dibentuk (Kusuma, L. S. W., 2017). Berdasarkan pernyataan sebelumnya, telah terlihat bahwa olahraga sepak bola telah berhasil menarik perhatian banyak orang di seluruh dunia.
Sepak bola merupakan permainan beregu, masing-masing regu terdiri atas sebelas pemain dan salah satunya adalah penjaga gawang. Permainan ini hampir seluruhnya dimainkan dengan menggunakan kaki, tetapi kadang kala menggunakan kepala dan dada. Khususnya untuk penjaga gawang diperbolehkan menggunakan tangan dan lengannya didaerah kotak enam belas meter/area pinalti. Dalam permainan sepak bola terdapat beberapa teknik dasar dimana teknik yang satu dengan yang lainnya sangat erat kaitannya.

Adapun teknik dasar yang dimaksud adalah passing, shooting, dribbling, controlling, dan heading, untuk memperoleh teknik dasar sepak bola yang baik dan benar diperlukan latihan yang baik, terprogram dan dilakukan dengan rutin dan penuh kedisiplinan (Prakarsa, R. A., 2020).

Di dalam sepak bola faktor teknik merupakan salah satu faktor yang menentukan dalam permainan sepak bola. Ada beberapa teknik dasar sepak bola, salah satunya teknik shooting. Menurut Mielke (2007:71) "Shooting sangat penting ketika pemain dan bola berada di daerah pinati 
lawan kecuali jika seorang pemain dihalangi atau dijaga ketat oleh pemain bertahan lawan, tindakan yang tepat di dalam daerah pinalti adalah melakukan shooting". Shooting merupakan satu teknik dasar yang harus mendapatkan perhatian yang lebih dari pelatih terhadap pemain. Prinsip dalam sepak bola adalah membuat gol sebanyak mungkin ke gawang lawan dan mencegah jangan sampai lawan membuat gol ke gawang sendiri. Dalam permainan sepak bola, menendang paling banyak dilakukan pemain jika dibandingkan dengan unsur teknik lainnya. Menendang merupakan salah satu usaha untuk memindahkan bola dari suatu tempat ketempat lain dengan menggunakan kaki.

Gerakan shooting terlihat sangat mudah, akan tetapi jika kita tidak memiliki teknik yang baik maka kita akan kesulitan dalam melakukan shooting. Dalam melakukan shooting terdapat beberapa teknik dasar yaitu dengan menggunakan kaki bagian dalam dan kaki bagian luar (Haviz, M., \& Syahara, S., 2018). Untuk memperoleh teknik shooting yang baik maka harus dilakukan latihan yang terprogram. Tanpa ada latihan yang terprogram dan dimulai sejak dini maka peningkatan hasil shooting akan sulit untuk tercapai.
Hasil shooting merupakan faktor penentu dalam permainan sepak bola, tidak sedikit tim yang memiliki penyelesaian akhir (shooting) yang buruk memperoleh hasil yang tidak bagus. Kurangnya hasil shooting dalam pertandingan dikarenakan kurangnya latihan untuk shooting pada waktu latihan berlangsung. Hal inilah yang ditemukan pada Sekolah Sepak Bola TGM Medan.

Pada saat peneliti melakukan observasi di Sekolah Sepak Bola TGM Medan selama satu minggu yang dimulai pada tanggal 3 Februari 2020, dari hasil observasi terlihat bahwa hasil shooting dari pemain tersebut masih belum maksimal. Setelah itu peneliti melakukan observasi pada saatu pemain melakukan pertandingan, bahwa saat melakukan shooting lebih sering melenceng dari pada mengarah ke gawang sehingga tidak terciptanya gol. Pemain selalu terburu-buru dalam melakukan shooting sehingga bola sering melenceng ke samping kiri, kanan dan ke atas gawang. Hal ini disebabkan beberapa faktor salah satunya adalah kurangnya tahap latihan yang dikhususkan melatih shooting dan latihan yang kurang bervariasi.

Hal ini diperkuat lagi dengan diadakannya tes pendahuluan kepada atlet dimana dari hasil tes pendahuluan 
Pengaruh Variasi Latihan Penyerangan Dengan Menggunakan Inverted Winger Terhadap Hasil Shooting Dalam Permainan Sepak Bola Pada Atlet SSB TGM Medan

kemampuan atlet tersebut masih dalam kategori kurang-cukup.

Setelah itu peneliti melakukan wawancara dengan pelatih Sekolah Sepak Bola TGM Medan yaitu Bapak Heryanto, beliau mengatakan bahwa bentuk-bentuk variasi latihan shooting yang dilakukan pelatih masih kedikit.

Dari hasil pengamatan dan wawancara penulis diatas, salah satu latihan yang diajukan penulis untuk meningkatkan hasil shooting adalah variasi latihan penyerangan menggunakan inverted winger terhadap hasil shooting. Bentuk latihan ini diharapkan bisa memberikan dampak yang positif terhadap hasil shooting dari pemain tersebut. Disebabkan selama ini pelatih kurang menerapkan model latihan variasi shooting. Sehingga pada saat bertanding, serta latihan hasil tes kemampuan shooting masih rendah.

Berdasarkan uraian dan penjelasan di atas, penulis menyimpulkan bahwa perlu diadakan sebuah penelitian ilmiah untuk mencari latihan mana yang lebih efektif untuk hasil shooting. Maka penulis melakukan penelitian dengan judul "Pengaruh Variasi Latihan Penyerangan Dengan Menggunakan Inverted Winger Terhadap Hasil Shooting Permainan Sepak
Bola Pada Atlet SSB TGM Medan Tahun $2020 ”$.

\section{METODE}

Metode penelitian yang digunakan dalam penelitian ini adalah metode eksperimen (perlakuan). Variabel yang diteliti dalam penelitian ini yaitu variasi penyerangan dengan menggunakan inverted winger sebagai variabel bebas dan hasil shooting sebagai variabel terikat.

Sudjana (2002:6), populasi adalah totalitas semua nilai yang mungkin, baik hasil menghitung ataupun pengukuran, kuantitatif maupun kualitatif mengenai karakteristik tertentu, dari anggota kumpulan yang lengkap dan jelas yang ingin dipelajari sifat-sifatnya.

Yang menjadi populasi penelitian ini adalah pemain sepak bola Sekolah Sepak Bola TGM Medan. Sudjana (2002:6), adapun sebagian yang diambil dari populasi dsebut sampel. Yang menjadi sampel dalam penelitian ini adalah pemain SSB TGM tahun 2020 a) Terdaftar sebagai pemain di SSB TGM Medan, b) Berusia 13-15 Tahun, c) Sampel bersedia serta sehat jasmani dan rohani, d) Sampel tes baik, kurang dan kurang baik.

Tujuan penelitian ini adalah untuk mendapatkan informasi yang akurat tentang 
Pengaruh Variasi Latihan Penyerangan Dengan Menggunakan Inverted Winger Terhadap Hasil Shooting Dalam Permainan Sepak Bola Pada Atlet SSB TGM Medan

Perngaruh variasi latihan penyerangan dengan menggunakan inverted winger terhadap hasil shooting permainan sepak bola pada atlet ssb tgm Medan tahun 2020. Nurhasan (1968:22) "Dalam mengukur kemampuan shooting, dipergunakan tembok atau gawang sebagai sarana dengan diberikan nilai pada sasaran tersebut". Teknik memperoleh data adalah dengan cara test dan pengukuran.

\section{HASIL DAN PEMBAHASAN}

Dari hasil pre-test pada variasivariasi latihan penyerangan dengan menggunakan inverted winger terhadap peningkatan hasil shooting dalam permainan sepak bola diperoleh data dengan nilai rata rata 50 dengan simpangan baku 4,67 sedangkan hasil post-test diperoleh dengan rata - rata 50,1 dan simpangan baku 7,89. Dari rata - rata pre-test dan post-test didapat nilai beda 9,5 dengan simpangan baku beda 5,19 sehingga didapat $t_{\text {hitung }} 5,79$.

1. Uji Normalitas

Pengujian normalitas data dengan mengunakan uji Lilifors, dari kolom daftar pre-test kelompok variasi-variasi latihan shooting terhadap peningkatan shooting sepakbola didapat $\mathrm{L}_{0}=0,142$ dan $\mathrm{L}_{\text {tabel }}=$ 0,258 dengan $\mathrm{n}=10$ dan taraf $\alpha=0,05$, karena $\mathrm{L}_{\text {hitung }}<\mathrm{L}_{\text {tabel }}$ dapat disimpulkan bahwa sampel berasal dari populasi yang normal. Dari kolom daftar post-test kelompok variasi-variasi Latihan shooting terhadap peningkatan shooting sepakbola didapat $\mathrm{L}_{0}=0,213$ dan $\mathrm{L}_{\text {tabel }}=0,258$ dengan $\mathrm{n}=10$ dan taraf $\alpha=0,05$, karena $\mathrm{L}_{\text {hitung }}<\mathrm{L}_{\text {tabel }}$ dapat disimpulkan bahwa sampel berasal dari populasi yang normal.

2. Uji Homogenitas

Uji homogenitas dari data pre-test dan post-test dari variasi-variasi latihan shooting sepakbola di dapat $\mathrm{F}_{\text {hitung }}=2,92$ diketahui $\mathrm{n}=10 \quad \mathrm{v}=\mathrm{N}-1=10-1=9$ sehingga di dapat $\mathrm{F}_{(0,05)(9,9)}=3,18$ dengan taraf nyata $\alpha=0,05$ maka $F_{\text {hitung }}<F_{\text {tabel }}$ $(2,92<3,18)$ dapat disimpulkan bahwa data berasal dari varians yang homogen.

\section{Uji Hipotesis}

Pengujian Hipotesis dilakukan dengan uji-t berpasangan untuk mengetahui pengaruh dari variasi-variasi latihan shooting terhadap peningkatan shooting sepakbola. Berdasarkan hasil perhitungan yang dilakukan maka diproleh $\mathrm{T}_{\text {hitung }}$ sebesar 5,79. Selanjutnya nilai tersebut dibandingkan dengan nilai $\mathrm{T}_{\text {tabel }}$ dengan $\mathrm{dk}=\mathrm{n}-1 \quad(10-1=9)$ pada taraf signifikan $\alpha=$ 0,05 adalah 2,26 dengan demikian $\mathrm{T}_{\text {hitung }}>$ $\mathrm{T}_{\text {tabel }}(5,79>2,26)$. Hal ini berarti $\mathrm{H}_{0}$ 
Pengaruh Variasi Latihan Penyerangan Dengan Menggunakan Inverted Winger Terhadap Hasil Shooting Dalam Permainan Sepak Bola Pada Atlet SSB TGM Medan

ditolak $\mathrm{H}_{a}$ diterima. Dengan demikian dapat disimpulkan bahwa secara signifikan variasi latihan penyerangan dengan menggunakan inveted winger memberikan pengaruh terhadap peningkatan hasil shooting pada atlet SSB TGM Medan Tahun 2020.

Pembahasan hasil analisis data penelitian dimaksudkan untuk mempermudah dalam menarik kesimpulan hasil penelitian. Berdasarkan perhitungan dan kriteria hipotesis yaitu Ho ditolak dan Ha diterima, karena dari data diperoleh thitung > t-tabel ketika di uji dengan uji-t. Maka, disimpulkan bahwa variasi latihan penyerangan dengan menggunakan inverted winger sangat berpengaruh atau memiliki pengaruh yang signifikan terhadap hasil shooting dalam permainan sepak bola.

Gerakan shooting terlihat sangat mudah, akan tetapi jika kita tidak memiliki teknik yang baik maka kita akan kesulitan dalam melakukan shooting (Yoland, S., \& Komaini, A., 2019). Dalam melakukan shooting terdapat beberapa teknik dasar yaitu dengan menggunakan kaki bagian dalam dan kaki bagian luar (Haviz, M., \& Syahara, S., 2018). Untuk memperoleh teknik shooting yang baik maka harus dilakukan latihan yang terprogram. Tanpa ada latihan yang terprogram dan dimulai sejak dini maka peningkatan hasil shooting akan sulit untuk tercapai.

\section{KESIMPULAN}

Berdasarkan hasil penelitian maka dapat disimpulkan bahwa terdadpat pengaruh yang signifikan dari variasi latihan penyerangan dengan menggunakan inveted winger terhadap hasil shooting dalam permainan sepak bola pada atlet ssb tgm Medan tahun 2020.

\section{DAFTAR PUSTAKA}

Haviz, M., \& Syahara, S. (2018). Pengaruh Variasi Latihan Daya Ledak Otot Tungkai Terhadap Akurasi Shooting SSB Putra Wijaya Padang. Jurnal JPDO, 1(1), 46-49.

Junaidi, A., Sugihartono, T., \& Sutisyana, A. (2018). Pengaruh Latihan Variasi Shooting Ke Arah Gawang Terhadap Akurasi Shooting Dalam Permainan Sepak Bola Pada Pemain U-14 Ssb Tunas Muda Bengkulu. Kinestetik: Jurnal Ilmiah Pendidikan Jasmani, 2(2), 126-132.

Kumbara, H. (2018). Perbedaan Variasi Latihan Juggling dan Rasio Koordinasi Mata-Kaki Terhadap Hasil Kontrol Bola dari Tendangan Jarak Jauh Sepak Bola. Halaman Olahraga Nusantara (Jurnal Ilmu Keolahragaan), 1(1), 1-16.Mielke, Danny. (2003). Dasar-Dasar Sepakbola. Jakarta: Human Kinetics.

Kusuma, L. S. W. (2017). Pengaruh Latihan Circuit Training Terhadap 
Pengaruh Variasi Latihan Penyerangan Dengan Menggunakan Inverted Winger Terhadap Hasil Shooting Dalam Permainan Sepak Bola Pada Atlet SSB TGM Medan

Peningkatan Vo2max Pemain Sepak Bola Ekacita FC. Gelora: Jurnal Pendidikan Olahraga dan Kesehatan, 4(2), 80-83.

Nurhasan (1986), Tes dan Pengukuran. Jakarta, Departemen Pendidikan dan Kebudayaan

Prakarsa, R. A. (2020). Pengaruh Variasi Latihan Plyometric, terhadap Akurasi Shooting Pemain Akademi PSP Padang. Jurnal Patriot, 2(1), 193-205.

Sudjana (2002), Metode Statistik. Bandung, Tarsito Bandung.

Yoland, S., \& Komaini, A. (2019). Pengaruh Latihan Model Shadow Untuk Meningkatkan Keterampilan Shooting Dalam Permainan Sepak Bola. Jurnal Stamina, 2(11), 1-11. 